\title{
Clinical profile of multiple myeloma in a tertiary medical college northern Kerala, India
}

\author{
Ramani P.N ${ }^{*}$, Sreeraj $V^{2}$, Kanniyan Binub ${ }^{3}$ \\ ${ }^{1-3}$ Assistant Professor, ${ }^{1}$ Dept. of General Medicine, ${ }^{3}$ Dept. of Community Medicine, ${ }^{1}$ Dr. Somervell Memorial CSI Medical College, \\ Kerala, ${ }^{2}$ Kerala Health Service, Kerala, ${ }^{3}$ MES Medical College, Perinthalmanna, Kerala, India \\ *Corresponding Author: Ramani P.N \\ Email: kanniyanbinub@gmail.com
}

\begin{abstract}
Introduction: Multiple myeloma is a clonal plasma cell disorder which varies its clinical course ranging from relatively indolent form to frankly aggressive neoplasia.

Objectives: To study the clinical profile of Multiple myeloma.

Materials and Methods: Descriptive study was conducted at a tertiary medical College in Kerala. 70 patients of Multiple myeloma was found with help of laboratory work up including urine Bence Jones with heat coagulation method. Serum albumin, calcium, uric acid was also done using standard biochemical kits. X-ray of Thoracic, Lumbar spine, Humerus, Hip region was evaluated. The frequency of variables was expressed as proportions and analysed.

Results: The mean age of males was 62 and females 59 appropriately. The male/female ratio of Multiple myeloma was found to be 1.6:1. The associated neurological symptoms were root pain for $14.3 \%$ of patients. Almost $8.6 \%$ had paraparesis and $2.9 \%$ were suffering from paraplegia and $1.4 \%$ had quadriplegia, paraesthesia, buldging right eye and diplopia. Anemia was found in $87.1 \%$ and ESR was raised above 30 in $92.8 \%$ of patients. The total count more than Eleven thousand was found for $10 \%$ and less than four thousand for $1.4 \%$ of patients. Easnophilia was seen among $7.1 \%, 1.4 \%$ of patients had Peripheral smear $>10 \%$ and Electrophoresis $\mathrm{M}$ band was seen in $78.6 \%$ of patients. Lytic lesions on X- Ray Skull neck were found in $62.9 \%$ and X Ray Spine were found in $1.4 \%$ of patients.

Conclusion: 70 cases detected at a tertiary Medical College at Northern Kerala in a year indicate significant incidence of the disease. Professional Medical Associations should give importance to this topic and case studies of Multiple Myeloma should be included in medical conferences to raise the competence of doctors regarding the disease.
\end{abstract}

Keywords: Multiple Myeloma, Northern Kerala.

\section{Introduction}

Malignant proliferation of plasma cells derived from a single clone is termed as Multiple Myeloma. The Plasma cell dyscrasias is broad heading which include this type of diseases. Multiple myeloma is the second most common hematological malignancy after non hodgkins lymphoma and it accounts for $15 \%$ of all hematological malignancies. The incidence of this disease increases with age in a spectrum of 4/lac in the general population to around 30/lac in over 25 years population. Even though lots of advancements have been made in the pathogenesis and etiology of this disease, it has still not made its way into the category of curable diseases. ${ }^{1}$

Egyptian mummies showered light to describe diseases which were similar to Multiple myeloma. In 1844, Samuel Solley reported a case of myeloma in Sarah Newbury. He described it as "mollitis ossium". Together with Bence Jones; he found that the urine analysis of the patient showed a protein with the heat properties often observed for urinary light chains. It later on came to be known as the Bence Jones Protein. MacIntyre and Dalrymple described the properties of the affected bone in the same patient and MacIntyre called it Mollitis and Fragillis ossium. ${ }^{2,3}$

As per the GLOBOCAN/IARC data, the worldwide Age Standardized Rate (ASR) for incidence of MM is $1.4 / 1,00,000$ population accounts to $1,00,000$ new cases every year. In the US as per the SEER data, the ASR for incidence is higher at 5.8/1, 00,000 population accounting for 21,000 new cases each year. Worldwide the 5 year prevalence of the disease is $2,10,697$ or 4.3/1, 00,000 population. The ASR for MM incidence in India is $0.7 / 1$, 00,000 population amounting to about 6,800 new cases a year.4-6

Present clinical research focuses on the balance between treatment efficacy and quality of life, the optimum sequencing of treatment options, the question of long-term remission and potential cure by multimodal treatment, the pre-emptive treatment of high-risk smoldering myeloma, and the role of maintenance. Upcoming results of ongoing clinical trials, together with a pipeline of promising new treatments, raise the hope for continuous improvements in the prognosis of patients with myeloma in the future. ${ }^{7}$ The introduction of high-dose melphalan with autologous stemcell transplantation and the availability of moleculartargeted novel agents such as immune-modulatory drugs and proteasome inhibitors have dramatically changed the treatment strategies for MM. Achievement of a high response rate resulted in the extension of overall survival, but further research and the development of more multimodality therapeutic approaches is warranted to cure this disease. ${ }^{8}$

The reclassification of a subset of patients with smoldering MM, based on high-risk biomarkers, and the development of the revised international staging system are among the key new developments in diagnosis and staging. ${ }^{9}$ Compared with MM patients diagnosed in earlier years, those diagnosed after 2010 had higher rates of novel therapy use and better survival outcomes; patients diagnosed in 2012 were 1.25 times more likely to survive 2 years than those diagnosed in $2006 .^{10}$ 
The disease diagnosis is quite difficult and thereby patients get diagnosed very late moving to complications and late stage of the disease. This study is an attempt to study the profile of Multiple myeloma of Northern Kerala as there are only few studies from this part of the country.

\section{Materials and Methods}

Seventy patients of multiple myeloma admitted to the Oncology department and department of Medicine at Government Medical College Hospital Calicut were studied for duration of six months. The data was collected using convenient sampling method. It was an observational study with an objective to look into clinical profile of multiple myeloma. All the new cases of multiple myeloma admitted to the department of medicine and Department of Medicine at Government Medical College Hospital Calicut were included in the study. The diagnosis of multiple myeloma was based on the following staging. ${ }^{11}$

\section{Diagnosis of Multiple Myeloma Major Criteria}

1. $\mathrm{I}=$ Plasmacytoma on tissue biopsy

2. $\mathrm{II}=$ Bone marrow with greater than $30 \%$ plasma cells

3. $\mathrm{III}=$ Monoclonal globulin spike on serum protein electrophoresis, with an immunoglobulin $\mathrm{G}(\mathrm{IgG})$ peak of greater than $3.5 \mathrm{~g} / \mathrm{dL}$ or an immunoglobulin $\mathrm{A}(\operatorname{IgA})$ peak of greater than $2 \mathrm{~g} / \mathrm{dL}$, or urine protein electrophoresis (in the presence of amyloidosis) result of greater than $1 \mathrm{~g} / 24 \mathrm{~h}$.

\section{Minor Criteria}

$\mathrm{a}=$ Bone marrow with $10-30 \%$ plasma cells

$\mathrm{b}=$ Monoclonal globulin spike present but less than category III

$\mathrm{c}=$ Lytic bone lesions

$\mathrm{d}=$ Residual normal immunoglobulin M (IgM) level of less than $50 \mathrm{mg} / \mathrm{dL}, \operatorname{IgA}$ level of less than $100 \mathrm{mg} / \mathrm{dL}$, or $\operatorname{IgG}$ level of less than

$600 \mathrm{mg} / \mathrm{dL}$

The following combinations of findings are used to make the diagnosis:

I plus $b$

I plus c

19

I plus $\mathrm{d}$
II plus b

II plus c

II plus d

III plus a

III plus c

III plus d

a plus $b$ plus $\mathrm{c}$ or a plus $\mathrm{b}$ plus $\mathrm{d}$

The inclusion criteria included increased numbers of abnormal, atypical or immature plasma cells in the bone marrow or histological proof of plasmacytoma, presence of an M-protein in the serum or urine, bone lesions consistent with those of multiple myeloma. The exclusion criteria were Monoclonal gammopathy of undetermined significance (MGUS), smoldering multiple myeloma, solitary plasmacytoma, plasma cell leukemia. All the 70 patients were subjected to detailed history taking and meticulous clinical examination. Laboratory work up - Biochemical work up included urine Bencejones done with the heat coagulation method, serum albumin, calcium, uric acid done using standard biochemical kits. Serum immune electrophoresis was done using the agar gel electrophoretic method. Complete hemogram and bone marrow aspiration studies were done. They were analysed by the Pathologist at the department of Pathology Calicut Medical College. Skeletal survey - X-ray skull PA and lateral view, X-ray pelvis PA and lateral view, X-ray cervical, thoracic, lumbar spine PA and lateral view, chest X-ray PA and lateral view, $\mathrm{X}$-ray humerus PA and lateral view, X-ray hip and femur PA and lateral view was done in all patients. All the data was entered into excel and transferred to Spss version 16 . The data was expressed in frequency and depicted with appropriate tables and graphs.

\section{Results}

Multiple Myeloma cases comprises of 43 males and 27 females. Most of them (60\%) belongs to 51 to 70 age group. The mean age of males were 62 and females were 59.

Body and bone pain were the complains for majority $(68.6 \%)$ of the patients followed by loss of appetite, loss of weight, fever, low back ache, bleeding manifestation, cough, chest pain, constipation, vomiting, pain abdomen, bleeding, odema, oliguria, dysurea, purulent discharge nose, thirst.

Table 1

\begin{tabular}{|l|c|c|c|c|c|c|}
\hline Symptoms & \multicolumn{2}{|c|}{ Male } & \multicolumn{2}{c|}{ Female } & \multicolumn{2}{c|}{ Total } \\
\hline & Number & \% & Number & \% & Number & \% \\
\hline Bone pain & 31 & 72.1 & 17 & 63 & 48 & 68.6 \\
\hline Body pain & 31 & 72.1 & 17 & 63 & 48 & 68.6 \\
\hline Fever & 12 & 27.9 & 7 & 25.9 & 19 & 27.1 \\
\hline Bleeding Manifestation & 4 & 9.3 & 2 & 7.4 & 6 & 8.6 \\
\hline Odema & 2 & 4.7 & 0 & 0 & 2 & 2.9 \\
\hline Oliguria & 2 & 4.7 & 0 & 0 & 2 & 2.9 \\
\hline
\end{tabular}


Table 2

\begin{tabular}{|l|c|c|}
\hline & Number & Percentage \\
\hline Anemia & 61 & 87.1 \\
\hline ESR & 65 & 92.8 \\
\hline Total Count & & \\
\hline$<4000$ & 1 & 1.4 \\
\hline$>11000$ & 7 & 10 \\
\hline Easnophilia & 5 & 7.1 \\
\hline Peripheral Smear-Plasma $>10 \%$ & 1 & 1.4 \\
\hline M Band & 55 & 78.6 \\
\hline X Ray - Skull neck & 44 & 62.9 \\
\hline X Ray - Skull Spine & 1 & 1.4 \\
\hline
\end{tabular}

The associated neurological symptoms were root pain for $14.3 \% .8 .6 \%$ had paraparesis and $2.9 \%$ were suffering from paraplegia. $1.4 \%$ had quadriplegia, paraesthesia, buldging right eye and diplopia. The signs elicited were pallor for $84.3 \%$ and $27.1 \%$ patients had increase in temperature. Bleeding manifestation was found out in $8.6 \%$. Clubbing, Lymphadenopathy and oral candidiasis was seen for $1.4 \%$. Spine tenderness was elicited for $32.9 \%$. Rib tenderness was there for $8.6 \%$. Swellings were seen for $7.1 \%$ and pelvic tenderness for $5.1 \%$.

Anemia was found in $87.1 \%$ and ESR was raised above 30 in $92.8 \%$. The total Count more than Eleven thousand was found for $10 \%$ and less than four thousand for $1.4 \%$. Easnophilia was seen among $7.1 \%$ and $1.4 \%$ patients had Peripheral smear $>10 \%$. Electrophoresis $\mathrm{M}$ band was seen in $78.6 \%$. X- Ray Skull neck lytic lesions were found in $62.9 \%$ and X-Ray Skull Spine lytic lesions were found in $1.4 \%$.

\section{Discussion}

The male/female ratio of Multiple myeloma is 1.4:1 and mean 5-year survival rate of $33 \% .^{12}$ In our study Multiple Myeloma cases comprises of 43 males and 27 females and most of them (60\%) belongs to 51 to 70 age group and male/female ratio of Multiple myeloma is 1.6:1. The mean age of males were 62 and females were 59.A study conducted by Fousad et $\mathrm{al}^{13}$ found male to female ratio was 1.3:1. Mean age of the patients in the study population was 62 years. Diwan et al ${ }^{14}$ found that out_of total 20 patients, 10 were males and 10 were females with_sixth decade as the common age group at presentation. The age of patients ranged from 39 to 83 years with a mean age_of $64 \pm 10.77$ years. Seventh decade was found to be the most common age group in our study population. Mean age of the patients in the study population was 62 years and one_patient was above 70 years of age.

Fousad et $\mathrm{al}^{13}$ found that the commonest symptoms noticed were fatigue $32(100 \%)$ and bone pain 31 (96.9\%). 6 (18.8\%) patients had hypercalcemia and 7 (21.9\%) patients had elevated serum creatinine levels. Diwan et $\mathrm{al}^{14}$ found common clinical symptoms were bone pains, localized body swelling, fever, generalized weakness and fatigue and motor weakness of lower limbs. Clinical examination revealed pallor in $80 \%$ patients, bony tenderness in $85 \%$ patients and $55 \%$ patients presented with infections.

Majority $29(90.6 \%)$ of patients had normal white blood cell count, $2(6.3 \%)$ of them had leukocytosis and $1(3.1 \%)$ had leucopenia. Five (15.6\%) cases had thrombocytopenia.

All patients had bone marrow plasmacytosis more than $10 \%$ on marrow examination. The percentage of plasma cells $>70 \%$ was seen in $2(6.3 \%)$ cases and between $50 \%$ and $70 \%$ in $3(9.4 \%)$ and between $10 \%$ and $30 \%$ in 19 $(59.4 \%)$ cases of study population. The mean bone marrow plasma cell percentage before therapy was found to be $31.26 \% \pm 19.97 \%$ in Fousad et al ${ }^{13}$ study. Diwan et $\mathrm{al}^{14}$ found Hematological features were anemia in all (100\%), median $\mathrm{Hb}$ concentration was $9.34 \mathrm{~g} / \mathrm{dL}$ and elevated ESR was present in all $(100 \%)$ cases. Rouleaux formation was observed in 7 patients $(35 \%)$ at presentation white blood cells count was less than 6000 in 4 patients (20\%) and platelet count was less than $1 \mathrm{lakh} / \mathrm{mm} 3$ in 2 patients (10\%) and greater than 4 lakh in 1 patient $(5 \%)$. Serum creatinine of more than $1.9 \mathrm{mg} / \mathrm{dL}$ was seen in 6 patients $(30 \%)$ at presentation. Hypercalcemia was observed in one patient (5\%). All patients had a presence of $\mathrm{M}$ band on serum protein electrophoresis, whereas $30 \%$ patients had urinary Bence Jones protein positive.

According to Diwan et al (14) 29 (91\%) of 32 had lytic lesions in the skull. All patients in study group (100\%) had the presence of $\mathrm{M}$ band on serum protein electrophoresis and $\gamma$-region was the most frequent location of the monoclonal band. 6 patients (30\%) had urinary Bence Jones protein. Among skeletal involvement, 19 patients $(85 \%)$ had osteolytic lesions, 8 patients $(40 \%)$ had generalized osteoporosis, 7 patients $(35 \%)$ had pathological fractures. Spine and skull were the common sites of involvement $60 \%$ and 55\% respectively. One patient did not have skeletal involvement. Bone marrow examination revealed the presence of more than $50 \%$ plasma cells in 9 cases $(45 \%), 7$ patients $(35 \%)$ had $10-30 \%$ plasma cells 4 patients $(20 \%)$ had plasma cells in the range of 30-50\%. 27 (84\%) had lytic lesions in the spine. ${ }^{11}$ According to diwan et al, ${ }^{14}$ Hematological features were anemia in all $(100 \%)$, median $\mathrm{Hb}$ concentration was $9.34 \mathrm{~g} / \mathrm{dL}$ and elevated ESR was present in all (100\%) cases. Rouleaux formation was observed in 7 patients $(35 \%)$ at presentation white blood cells count was less than 6000 in 4 patients $(20 \%)$ and 
platelet count was less than $1 \mathrm{lakh} / \mathrm{mm} 3$ in 2 patients $(10 \%)$ and greater than 4 lakh in 1 patient $(5 \%)$. Serum creatinine of more than $1.9 \mathrm{mg} / \mathrm{dL}$ was seen in 6 patients $(30 \%)$ at presentation. Hypercalcemia was observed in one patient $(5 \%)$. All patients in study group $(100 \%)$ had the presence of $\mathrm{M}$ band on serum protein electrophoresis and $\gamma$-region was the most frequent location of the monoclonal band. 6 patients $(30 \%)$ had urinary Bonce Jones protein. Among skeletal involvement, 19 patients $(85 \%)$ had osteolytic lesions, 8 patients $(40 \%)$ had generalized osteoporosis, 7 patients $(35 \%)$ had pathological fractures. Spine and skull were the common sites of involvement $60 \%$ and 55\% respectively. One patient did not have skeletal involvement. Bone marrow examination revealed the presence of more than 50\% plasma cells in 9 cases (45\%), 7 patients (35\%) had $10-30 \%$ plasma cells 4 patients $(20 \%)$ had plasma cells in the range of $30-50 \% .50 \%$ patients had fractures, may be due to delayed presentation by the patients and late diagnosis by attending physicians.

\section{Conclusion}

Multiple myeloma is a well reported entity in the medical literature from western world. The fact that 70 cases detected in one year indicate significant incidence of the disease in Northern Kerala. No definite predisposing factors could be made out. Male female ratio is 1.6:1 is noted. Bone pain and body pain are the most common symptoms. Anemia is present in all cases. ESR is increased in $95 \%$ patients. Hypercalcemia was seen only $2.5 \%$ and almost $50 \%$ had fractures. The physician should be able to think probable diagnosis as multiple myeloma and treat earlier to prevent fractures. Continuing Medical Education should incorporate topics and case studies of Multiple Myeloma to empower diagnosing capacity of physicians.

Conflict of Interest: None.

\section{References}

1. Tandon N. Consensus document for management of Multiple Myeloma. Indian Council Med Res 2017

2. Clamp JR. Some aspects of the first recorded case of multiple myeloma. Lancet 1967;2(7530):1354-6.

3. Bates SE. Multiple Myeloma. Clin Cancer Res 2011;17(6): 1224.

4. Swerdlow SH, Campo E, Harris NL. WHO Classification of Tumours of Haematopoietic and Lymphoid Tissues. Lyon, France: IARC; 2008:200-213. 4th ed. Lyon, France: IARC; 2008.

5. IACR Globocan.2019. Available from http://www.iacr.com.fr/index.php?option=com_content\&view $=$ article $\&$ id $=101 \&$ Itemid $=578$

6. Seer.2019.Available from https://seer.cancer.gov/statfacts/more.html

7. Rolling S. Multiple Myeloma. Lancet 2015;385:2121-2.

8. Chou T. Multiple Myeloma: Recent Progress in Diagnosis and Treatment. J Clin Exp Hematopathol 2012;52(3):149-59.

9. Mel D. The Singapore Myeloma Study Group Consensus Guidelines for the management of patients with multiple myeloma. Singapore Med J 2017;58(2):55-71.

10. R Fonseca at al. Trends in overall survival and costs of multiple myeloma, 2000-2014. Leukemia 2017; 31 :19151921

11. Intechopen. $2018 \mathrm{https} / / / \mathrm{www}$. intechopen.com/books/updateon-multiple-myeloma/management-of-multiple-myeloma-indeveloping-countries.

12. Ries LAG, Melbert D, Krapcho M. (2007). SEER Cancer Statistics Review, 1975-2004. Bethesda, MD: National Cancer Institute. [online]. Available from

13. Fousad C, Gangadharan KV, Abdulla MC, Naryan R, Mohammed Ali MJ. Clinical profile of multiple myeloma in South India. Indian J Med Paediatr Oncol 2018;39:62-6.

14. Diwan AG, Gandhi SA, Krishna K, Shinde VP. Clinical profile of the spectrum of multiple myeloma in a teaching hospital. Med J DY Patil Univ 2014;7:185-8.

15. http://seer.cancer.gov/csr/1975_2004/ [Accessed November, 2012].

How to cite this article: Ramani PN, Sreeraj V, Binub $\mathrm{K}$. Clinical profile of multiple myeloma in a tertiary medical college northern Kerala, India. Int $\mathrm{J}$ Med Paediatr Oncol 2019;5(2):58-61. 